\title{
Kunt, Gergely. 2019: Kipontozva... Nemi eröszak második világháborús naplókban. ('Left Unsaid... Sexual Violence in World War Two Diaries'). Budapest: Osiris. 240 pp.
}

\author{
Reviewed by Agatha Schwartz, ${ }^{*}$ University of Ottawa
}

Gergely Kunt's study about sexual violence as depicted in Hungarian diaries of World War II expands the growing literature on the topic of sexual violence perpetrated during WWII, in this case, with a focus on Hungary. The author teaches at the University of Miskolc and is a social historian by training. In his research, he specializes in WWII diaries. In this new book Kunt offers an innovative approach when it comes to understanding the consequences of the mass rapes committed during and in the aftermath of WWII all over Europe and the former Soviet Union. He examines diaries written not only by selected Hungarian female victims of sexual violence (the topic of female victims of sexual violence in WWII is a fairly well-explored topic in both scholarly and popular literature and, more recently, also in film), but also some sources that illuminate the perspective of male perpetrators of sexual violence, which is still lesser known and researched. While Kunt zeroes in on the Hungarian context, he makes some reflections regarding Germany as well.

The author's analysis is first and foremost based on three diaries written by Hungarian women survivors of sexual violence perpetrated by the Red Army. Only one of these, the published diary of Radnóti Miklósné Gyarmati Fanni (Budapest: Jaffa, 2014) is known to the wider public and has had some scholarship written on it. Interestingly, Kunt refers to the author of this book using only her maiden name, which he explains by his intention to make Fanni Gyarmati herself the heroine of this narrative rather than leaving her in the shadow of her famous husband. The other two diaries were both still unpublished at the time when Kunt's book came out. One of them, written by Róza Bodó, is still unpublished, whereas the other, the diary of Erzsébet Bicskey, was made public in 2019 as an internal publication of the Hungarian National Archives under the title "Belső várkastély:” Bicskey Erzsébet, egy fiatal lány naplója 1940-1946 (“'Inside Castle:” Erzsébet Bicskey, a Young Woman’s Diary 1940-1946’). Kunt tells the fascinating story of this diary. The four original notebooks were found in the garbage container of a Budapest retirement residence by Piroska Szabó, a student at the time, who later became a librarian and one of the diary's editors. Szabó rescued the notebooks that had been discarded along with Bicskey's other belongings, following the latter's passing. (We can only speculate how many other important life documents may have been lost under similar circumstances.) In some of his chapters, Kunt refers to examples taken from other unpublished diaries by Hungarian

*agathas@uottawa.ca

(cc) BY

ULLS D-Serle
New articles in this journal are licensed under a Creative Commons Attribution 4.0 International License.

This journal is published by the University Library System of the University of Pittsburgh as part of its D-Scribe Digital Publishing Program and is cosponsored by the University of Pittsburgh Press 
Schwatrz, Agatha. "Kunt, Gergely. 2019: Kipontozva... Nemi eröszak második világháborús naplókban. ('Left Unsaid... Sexual Violence in World War Two Diaries'). Budapest: Osiris. 240 pp." Hungarian Cultural Studies. eJournal of the American Hungarian Educators Association, Volume 13 (2020) DOI: 10.5195/ahea.2020.408

women as well, but these remain unexplained and therefore create some confusion for the reader. Finally, in the last chapter of his book Kunt turns to the published diary of a Hungarian officer and medical doctor, Lajos Somorjai, Megjártam a Don-kanyart-Oroszország, 1942-1943 ('I Was at the Battle on the River Don - Russia 1942-1943,' Budapest: Rubicon, 2012), so as to also shed some light on sexual violence committed by Hungarian armed forces during WWII in the former Soviet Union.

Regarding his methodology, Kunt creates a clear distance from establishing a historical overview and examining memory politics around wartime sexual violence in Hungary; and he refers to Andrea Petö's works that have already explored these questions. His methodology is informed by a close reading of the diaries. The main object of his interest is the narrative strategies the women used to describe their ordeals and how they framed their survival. Building on Judith Herman's findings regarding the effects of sexual traumatization, Kunt reads the diaries of the three female authors as post-traumatic narratives. Additional trauma theories could have been used to strengthen the argument and make the analysis of the diaries less descriptive and more theoretical (the citations are sometimes unnecessarily long and parts of these are repeated in the analysis). A useful term that could have been explored, for example, would be "vocabulary of rupture" as developed by Urvashi Butalia in The Other Side of Silence: Voices from the Partition of India (2000) relating to trauma narratives by women who were raped during the Indian partition; this term is further explored by Schwartz in her 2017 analysis of Gyarmati's diary and other published rape narratives by and about Hungarian women (Agatha Schwartz, "Creating a 'Vocabulary of Rupture' Following WWII Sexual Violence in Hungarian Women Writers' Narratives.” Hungarian Cultural Studies 10: 81-95, at: http://ahea.pitt.edu/ojs/index.php/ahea/article/view/281/561).

Kunt's analysis of Gyarmati's diary is particularly successful in revealing an intersection in her narrative among the sometimes extreme violence the young woman experienced during the rapes, her Christian faith and Jewish background, and her class bias regarding victims of sexual violence from the lower classes, despite her sympathizing with communist ideas. What could have been elaborated more is the contradictory representation of the Soviets, to whom Gyarmati sometimes refers with a certain empathy, whereas at other times she uses the racist term "Mongols," a common denominator at the time both in Nazi Germany and beyond referring to people/s from the Soviet Union considered racially less valuable, and particularly to members of the Red Army coming from the Asian republics. The use of this problematic term in Gyarmati's diary is left uncommented by Kunt, although it could have built a very interesting bridge to similarly racist representations of women in the Soviet Union in Somorjai's memoir.

Erzsébet Bicskey's diary, while using a symbolic and metaphorical language when it comes to describing her experience of rape (something we can find in many other rape narratives as well), also develops an astonishingly modern vocabulary for the description of her positive sexual experiences with men with whom she later had love relationships. Kunt interprets this shift in Bicskey's narrative strategy as a clear break from the values of a patriarchal society and her Catholic upbringing, including the linguistic norms and training she received during her schooling at a convent. Descriptions such as "Our naked bodies pulsate with heat. ... His hard cock touches me, it is already in me. He penetrates me deeply, but it is still not enough." ('Mezítelen testünk forrón lüktet. ... Kemény fasza hozzám ér, már bennem is van. Mélyen behatol, de még most sem elég,' 115) could have been written by contemporary Hungarian women writers (i.e., Zsuzsa Forgács, Dóra Esze, and others) who expanded and redefined the vocabulary referring to female sexuality and the female body. In Bicskey's case, however, this 
Schwatrz, Agatha. "Kunt, Gergely. 2019: Kipontozva... Nemi eröszak második világháborús naplókban. ('Left Unsaid... Sexual Violence in World War Two Diaries'). Budapest: Osiris. 240 pp." Hungarian Cultural Studies. eJournal of the American Hungarian Educators Association, Volume 13 (2020) DOI: 10.5195/ahea.2020.408

shift to a clearly positive post-rape connotation of sexuality shows how writing can help in integrating traumatic memories to move beyond a traumatic past.

Róza Bodó's diary offers little information about the rapes she suffered by the Soviets. What makes this diary interesting to the reader is the episode of the time she spent in a refugee camp in Bavaria, where she ended up toward the end of the war. Bodó's description of life under American occupation breaks with the common perception that the Soviets were the only bad guys of WWII, whereas the Americans were nice to women and seduced them with chocolates. Kunt addresses the widespread sexual barter (which in times of war is often difficult to distinguish from rape) between the women and the American soldiers, and he also mentions sexual violence. Here he could have included more of the findings of German historian Miriam Gebhardt (Als die Soldaten kamen, 2015), who researched sexual violence committed by the Western Allies against German women, but her book is only referred to in a footnote. Similarly, Robert J. Lilly's Taken by Force: Rape and American GIs in Europe During WWII (2007) should have also been referenced. What Kunt rightly interprets as Bodó's strategy of forgetting both her unease about the sexual barter she engaged in and her past sexual trauma is her indulgence in dancing while at the camp. Again, the argument could have been made stronger here by referencing recent trauma research regarding the healing power of dance for survivors of sexual violence, as elaborated for example by Dörte Stanek in "Bridging Past and Present: Embodied Intergenerational Trauma and the Implications for Dance/Movement Therapy" (Body, Movement and Dance in Psychotherapy 10, no. 2, 2014: 1-12).

The last chapter of Kunt's book turns to the behavior of Hungarian armed forces in the Soviet Union with a focus on a critical analysis of Dr. Somorjai's diary. Kunt notes the important fact that since the Hungarian officer wrote this diary for his wife back in Hungary, the poor treatment of the local population (rape, heavy looting even of sacral objects, and destruction) is often downplayed or justified by the reality of the war. Thus, the Hungarian soldiers are essentially represented as poor victims of the circumstances, and the local women as cunning, dirty creatures. This anti-Slavic and essentially racist aspect in Somorjai's diary could have been theorized more, although Kunt does address the abuse of unequal power relations between the higher-class Hungarian men and the local peasant women, who are described as over-sexualized beasts all too ready to lift their skirts and seduce the helpless Hungarian men. The language used by Somorjai is often vulgar, barrack language ("All the civilian women here fuck." 'A civil nök pedig itt mind basznak,' 225). Although Kunt's reading of Somorjai's diary reveals a rather negative image of how the Hungarian armed forces treated the civilian Soviet population, and this analysis is further supported by his citing the findings of Tamás Krausz and Éva Mária Varga in A magyar megszálló csapatok a Szovjetunióban ('The Hungarian Occupying Forces in the Soviet Union,' 2013), Kunt's conclusion seems to somewhat undermine the results of his own analysis. While acknowledging that further research is needed to establish more reliable conclusions, he ends on a note that essentially downplays the violence of the Hungarians, ultimately suggesting that the Hungarian armed forces were more civil with Soviet women compared to what the violent Russians did to Hungarian women, which corroborates commonly held presumptions regarding sexual violence in WWII.

Similar misconceptions existed for decades regarding the behavior of the German Wehrmacht on the Soviet front. Consulting Regina Mühlhäuser's findings ("Eroberungen: Sexuelle Gewalttaten und intime Beziehungen deutscher Soldaten in der Sowjetunion, 1941 1945, " 2010; "Reframing Sexual Violence as a Weapon and Strategy of War: The Case of the German Wehrmacht during the War and Genocide in the Soviet Union, 1941-1944." Journal of 
Schwatrz, Agatha. "Kunt, Gergely. 2019: Kipontozva... Nemi erőszak második világháborús naplókban. ('Left Unsaid... Sexual Violence in World War Two Diaries'). Budapest: Osiris. 240 pp." Hungarian Cultural Studies. eJournal of the American Hungarian Educators Association, Volume 13 (2020) DOI: 10.5195/ahea.2020.408

the History of Sexuality 26, no. 3, September 2017: 366-401) to the contrary would have probably helped Kunt establish a more nuanced conclusion. This criticism notwithstanding, Kunt's book offers a captivating reading with his attempt to juxtapose the voices of the female victims of World War Two sexual violence with some voices of the male perpetrators, and as such it is an important step toward furthering our understanding of how sexual violence in wartime is framed by both sides and what it unleashes in both the short and the long term. 